\title{
South African recommendations for the management of rheumatoid arthritis: An algorithm for the standard of care in 2013
}

\author{
B Hodkinson, ${ }^{1} \mathrm{MB}$ BCh, FCP (SA), PhD; E van Duuren, ${ }^{2} \mathrm{MB}$ BCh; C Pettipher, ${ }^{3} \mathrm{MB}$ BCh, FCP (SA); \\ A A Kalla, ${ }^{4} \mathrm{MB} \mathrm{ChB}, \mathrm{FCP}(\mathrm{SA}), \mathrm{MD}, \mathrm{FCRP}$ (London) \\ ${ }^{1}$ Department of Medicine, Chris Hani Baragwanath Academic Hospital, University of the Witwatersrand, Johannesburg, South Africa \\ ${ }^{2}$ Jacaranda Hospital, Pretoria, South Africa \\ ${ }^{3}$ Wilgeheuwel Hospital, Johannesburg, South Africa \\ ${ }^{4}$ Department of Medicine, Division of Rheumatology, University of Cape Town and Groote Schuur Hospital, Cape Town, South Africa
}

As a South African Rheumatism and Arthritis Association (SARAA) initiative, these recommendations are offered with the aim of improving healthcare delivery and thereby enriching the quality of lives of those suffering from rheumatoid arthritis in South Africa.

\begin{abstract}
Updated treatment recommendations for the therapy of rheumatoid arthritis (RA) in South Africa advocate early diagnosis, prompt initiation of disease-modifying anti-rheumatic drugs (DMARDs), and an intense treatment strategy where disease activity is assessed with a composite score such as the Simplified Disease Activity Index (SDAI). Frequent assessments and escalation of therapy are necessary until low disease activity (LDA) (SDAI $\leq 11$ ) or ideally remission (SDAI $\leq 3.3$ ) is achieved. Synthetic DMARDs may be used as monotherapy or in combination, and can be co-prescribed with low-dose corticosteroids if necessary. Biologic DMARD therapy should be considered for patients who have failed a 6-month trial of at least 3 synthetic DMARDs. All RA patients in SA are at increased risk of tuberculosis (TB), in particular patients using anti-tumour necrosis factor (TNF) biologic therapy. These recommendations provide practical suggestions for the screening and management of $\mathrm{TB}$ and other comorbidities, and offer an approach to monitoring of RA patients.
\end{abstract}

S Afr Med J 2013;103(8):576-585. DOI:10.7196/SAMJ.7047

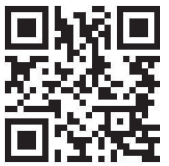

\section{Introduction}

Rheumatoid arthritis (RA) is a chronic inflammatory disease, which, if treated inadequately, leads to irreversible joint damage, resulting in deformities, disability and premature mortality. The disease occurs worldwide and affects approximately $1 \%$ of the population. ${ }^{[1,2]}$

Recently, there have been major developments in the management of RA. These include ( $i$ ) advances in the early diagnosis of the disease and evidence for the benefit of early therapy; (ii) better tools to assess response to therapy with the development of composite disease activity scores, allowing goal-directed therapy where the target is remission; and (iii) the emergence of biologic disease-modifying anti-rheumatic drugs (DMARDs). These strategies result in better control of inflammation, thus preventing joint damage and reducing disability. Against this background, the South African Rheumatism and Arthritis Association (SARAA) has proposed the development of an updated treatment strategy for the effective therapy of RA in South Africa (SA). These recommendations are aimed at all healthcare professionals managing RA, including rheumatologists, physicians, general practitioners, nurses and allied healthcare professionals.

SARAA adhered to the following ideologies when formulating these recommendations:

- They should be aimed at all healthcare professionals managing RA, including allied healthcare professionals, nurses, general practitioners, physicians and rheumatologists.

- There should be consultation with pivotal stakeholders in the final consensus of the document.

- They should be based on scientific evidence or, if unavailable, expert consensus.

- They should be recommendations and not a guideline. Management of RA is not cast in stone (and is likely to change again in the near future) and failure to adhere to them is not incriminating or negligent.
They represent what SARAA, as a professional body, recommends and set a certain standard of care that should be aimed for, from the very basic management to the highly sophisticated. Should practitioners not be able to offer expertise where appropriate, they may consider referral to a centre that does.

- There are limitations to all recommendations and they cannot cover all clinical problems, but should be detailed enough to cover common circumstances, yet concise enough to be practical to the reader.

- SA is a multi-faceted society and thus a 'one size fits all' policy is not rational for all practitioners and patients, but these recommendations should be insightful to treating practitioners and stakeholders.

- These recommendations should be disseminated widely.

\section{Scope}

The treatment strategy is presented in the form of an algorithm (Fig. 1), and is accompanied by a more in-depth discussion of key management principles. This algorithm provides a step-wise approach to treatment, to enable health authorities and practitioners to develop and support the most effective method of achieving and maintaining remission in RA patients in both public and private health sectors. The purpose is not to remove the physician's autonomy, and physicians must select the most appropriate therapeutic option, taking into consideration the patient's preferences.

\section{Methods}

For this guideline to be widely accepted, the following methodology has been followed. Evidence from the literature and from RA guidelines developed elsewhere in the world has been reviewed. An online survey sent to all SA rheumatologists was performed to assess the level of agreement with key points relating to RA therapy. Various stakeholders including the Department of Health, medical funders, the Registrar of Medical Schemes, patient representative bodies (i.e. the Arthritis 


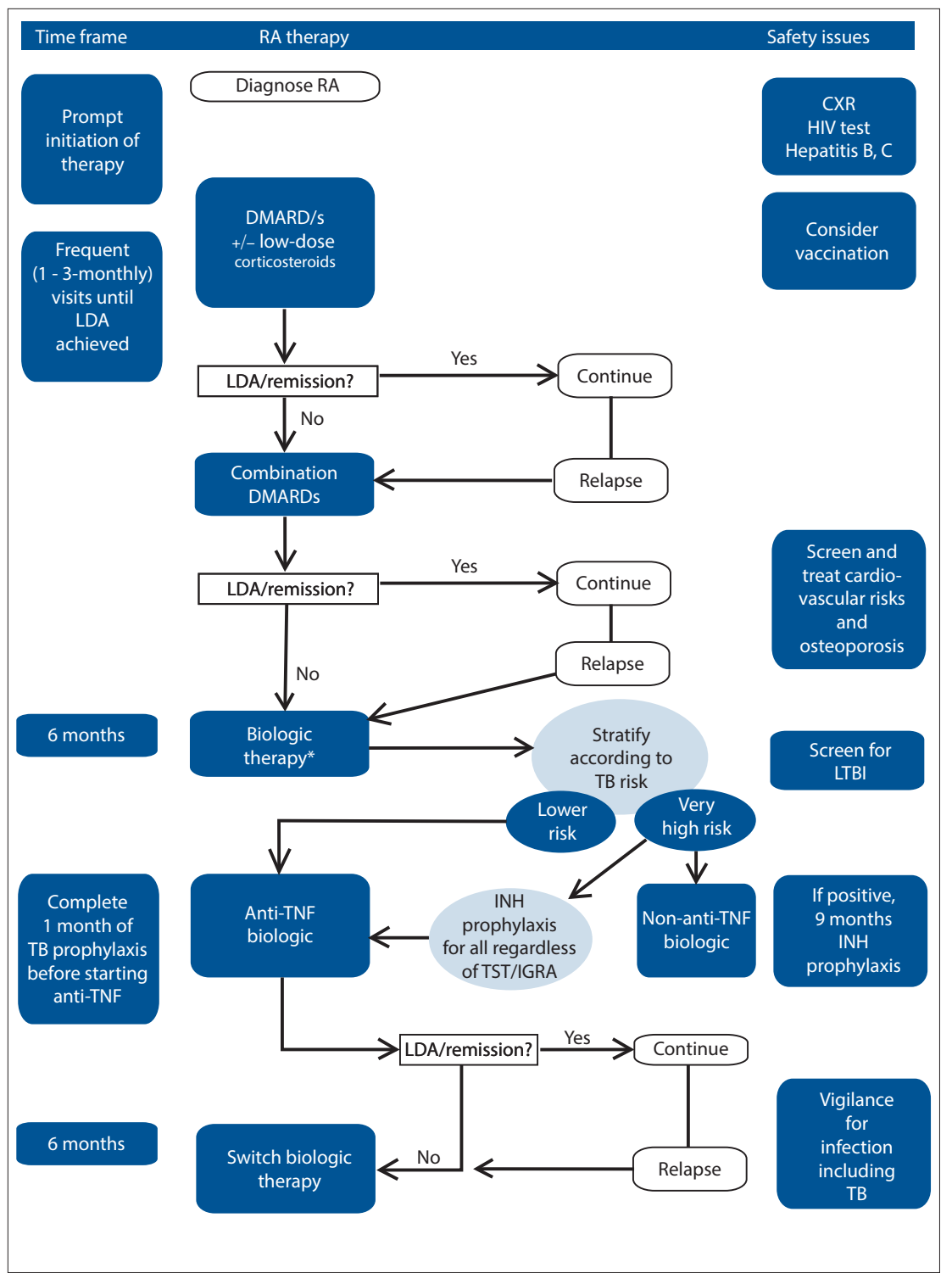

Fig. 1. Algorithm for management of rheumatoid arthritis in $S A . D M A R D=$ disease-modifying antirheumatic drug; $L D A=$ low disease activity $(S D A I \leq 11) ; C X R=$ chest $X$-ray; $T B=$ tuberculosis; $L T B I=$ latent TB infection; TST = tuberculin skin test; IGRA = IFN- $\gamma$ release assay. ${ }^{*}$ Biologic therapy should be considered in patients with high disease activity, or moderate disease activity in the presence of poor prognostic factor/s (seropositivity, early radiographic erosions, extra-articular disease or functional disability).

Foundation) and academic departments have been consulted.

\section{Key principles}

\subsection{Early diagnosis and treatment}

Untreated RA results in severe disability and loss of health-related quality of life. ${ }^{[3]}$ There is a direct relationship between the duration of uncontrolled inflammation and joint damage (as measured by bony erosions and joint space narrowing). ${ }^{[4]}$ Joint damage begins within the first $3-6$ months after disease onset and a narrow window of opportunity exists where early aggressive therapy of RA can suppress inflammation before irreversible joint destruction has occurred. $^{[5-7]}$ Thus, early diagnosis and

\subsection{Assessment}

\subsubsection{Disease activity}

There have been significant advances in the methods of scoring disease activity in RA, where the clinical examination of tender and swollen joints, global assessments and laboratory investigations are combined in a composite disease activity score. The 3 validated scores currently in use in SA are the 28-Joint Disease Activity Score (DAS-28), the Simplified Disease Activity Index (SDAI), and the Clinical Disease Activity Index (CDAI) (Table 3). ${ }^{[12-14]}$ These scores allow classification of the patient into a state of remission or low, moderate or high disease activity, providing a simple tool for assessing disease at each patient visit to guide therapeutic decisions. ${ }^{[15]}$

The results of clinical trials are expressed according to the percentage of patients achieving an ACR 20, ACR 50 or ACR 70 response. An ACR 20 response is defined by a $\geq 20 \%$ improvement in tender and swollen joint counts, and in 3 of the remaining 5 criteria. ${ }^{[16]}$ The ACR 50 and ACR 70 represent a 50\% or $70 \%$ improvement in these parameters, respectively. In general, the proportion of patients achieving an ACR 20 is higher than those achieving an ACR 50 or ACR 70.

\subsubsection{Goal-directed therapy}

In other fields of medicine, treatment targets have been defined and treatment aimed at achieving these targets has led to improved outcomes with less end-organ damage. Examples include $\mathrm{HbAlc}$ level in diabetes mellitus, blood pressure measurement in hypertension, and cholesterol level in dyslipidaemia. In RA, there is evidence that obtaining tight control of disease activity, with a pre-defined goal of low disease activity (LDA), or ideally, remission, to drive disease management decisions, allows better control of disease than routine clinic care. This intensive control strategy results in lower disease activity, better physical function and less structural damage, particularly when commenced in early disease. ${ }^{[17]}$ For this reason, RA patients commenced on therapy may require evaluation as frequently as monthly, with calculation of a composite disease activity score at each visit, and escalation of DMARD therapy, until LDA (SDAI $\leq 11$ ) or ideally remission (SDAI $\leq 3.3$ ) is achieved, after which time, less frequent assessments (3 - 6-monthly) are acceptable. The target of LDA or remission should be maintained as long as possible, keeping in mind the individual patient's risk for drugrelated complications or comorbid diseases.

\subsubsection{Disability}

Physical disability, with its negative consequences on personal care, employment and 
social life, can be measured with a self-administered questionnaire, the Health Assessment Questionnaire - Disability Index (HAQ-DI). ${ }^{[18]}$ In early disease, the HAQ-DI reflects joint inflammation and shows

\section{Table 1.2010 ACR/EULAR RA Classification Criteria*}

\begin{tabular}{|c|c|}
\hline Criteria & Score $^{\dagger}$ \\
\hline \multicolumn{2}{|l|}{ A. Joints } \\
\hline 1 large joint & 0 \\
\hline 2 - 10 large joints ${ }^{\ddagger}$ & 1 \\
\hline $1-3$ small joints $^{\varsigma}$ & 2 \\
\hline $4-10$ small joints & 3 \\
\hline$>10$ joints & 5 \\
\hline \multicolumn{2}{|l|}{ B. Serology } \\
\hline Negative RF and negative anti-CCP & 0 \\
\hline Low-positive RF or low-positive ACPA' & 2 \\
\hline High-positive RF or high-positive ACPA" & 3 \\
\hline \multicolumn{2}{|l|}{ C. Acute phase reactants } \\
\hline Normal CRP and ESR & 0 \\
\hline Abnormal CRP or ESR & 1 \\
\hline \multicolumn{2}{|l|}{ D. Symptom duration } \\
\hline$<6$ weeks & 0 \\
\hline$\geq 6$ weeks & 1 \\
\hline \multicolumn{2}{|c|}{ 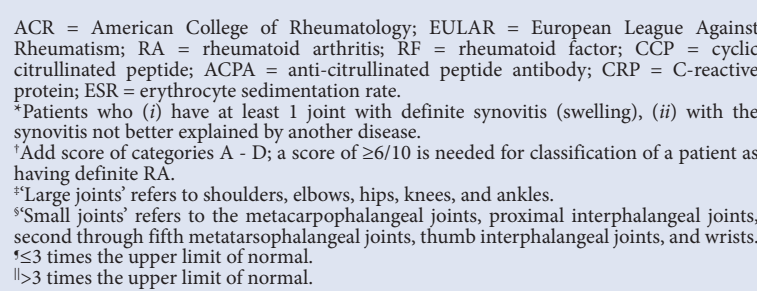 } \\
\hline
\end{tabular}

Table 2. 'S-factors' screening for early inflammatory arthritis (from Arthritis Care $\left.{ }^{[10]}\right)^{*}$

\begin{tabular}{ll}
\hline $\begin{array}{l}\text { Stiffness } \\
\text { Swelling }\end{array}$ & $\begin{array}{l}\text { Early morning stiffness lasting }>30 \text { min } \\
\text { Persistent swelling of } \geq 1 \text { joint, particularly } \\
\text { hand joints }\end{array}$ \\
MCP squeeze test & $\begin{array}{l}\text { Tenderness on squeezing across all } 4 \mathrm{MCP} \\
\text { joints }\end{array}$ \\
MTP squeeze test & $\begin{array}{l}\text { Tenderness on squeezing across the } \\
\text { metatarsal heads }\end{array}$ \\
MCP = metacarpophalangeal; MTP $=$ metatarsophalangeal. \\
${ }^{*}$ Referral to a rheumatologist is recommended if $\geq 1$ factor is present.
\end{tabular}

good correlation with clinical disease activity ${ }^{[19]}$ In established RA, physical function worsens annually as a consequence of irreversible joint damage. ${ }^{[20]}$ The score ranges from 0 (no disability) to 3 (severe disability).

\subsubsection{Radiography}

Baseline radiographs of hands and feet should be performed for diagnostic and prognostic purposes. Erosions seen within the first 2 years of disease are markers of aggressive disease, ${ }^{[21]}$ but normal X-rays do not exclude the diagnosis of RA. In addition, a chest X-ray (CXR) is appropriate to assess rheumatoid lung involvement, to exclude tuberculosis (TB) prior to commencing DMARDs and to provide a baseline in the event of pulmonary complications of therapy.

\subsubsection{Sonar and MRI}

Newer imaging modalities such as high-resolution ultrasound and magnetic resonance imaging (MRI) of peripheral joints allow detection of synovitis, joint space narrowing and erosions much earlier than is possible with conventional radiography. ${ }^{[22]}$ Precise visualisation of anatomical structures allows more accurate diagnosis of joint and soft tissue pathology in the RA patient, and facilitates accurate placement of intra-articular injections, but these are not yet part of routine patient management. ${ }^{[23]}$

\section{Therapy \\ 5.1 Synthetic DMARDs}

Methotrexate (MTX) is the most widely prescribed DMARD, and is recommended as first-line therapy in doses starting at $7.5-15 \mathrm{mg}$ weekly, with rapid dose escalation according to response and tolerability to a maximum of $25 \mathrm{mg}$ weekly. The drug has an excellent safety profile, and although mild elevation of liver enzymes is not infrequent, this is usually transient, and cirrhosis is rare. ${ }^{[24,25]}$ There is no evidence that higher doses are more effective, and they may increase toxicity. Antimalarials (chloroquine (CQ) or hydroxychloroquine, which is not currently available in SA), may be used as monotherapy for mild RA, or in combination with MTX for moderate to severe disease. Sulphasalazine (SSZ) is effective as monotherapy, and is particularly useful in patients in whom MTX is contraindicated, or as part of combination DMARD therapy. Similarly, leflunomide may be prescribed as monotherapy or co-prescribed with MTX. A summary of the doses, major side-effects and recommendations for monitoring patients is presented in Table 4, and further details have been given in previous SA guidelines for RA. ${ }^{[26]}$

Patients who have failed MTX monotherapy should be treated with combination synthetic DMARDs. The most commonly prescribed combination treatment is MTX, SSZ and CQ.

\subsection{Glucocorticoids}

Glucocorticoids (GCs) rapidly reduce symptoms of RA and may inhibit development of erosions, particularly in early RA when used in combination with DMARDs. ${ }^{[27]}$ However, side-effects limit their

Table 3. Disease activity formulas and categories

\begin{tabular}{|c|c|c|c|c|c|}
\hline \multirow[b]{2}{*}{ Index } & \multirow[b]{2}{*}{ Formula } & \multirow[b]{2}{*}{ Remission } & \multicolumn{3}{|c|}{ Disease activity } \\
\hline & & & Low & Moderate & High \\
\hline SDAI & $\mathrm{TJC}+\mathrm{SJC}+\mathrm{PGA}(\mathrm{cm})+\mathrm{DGA}(\mathrm{cm})+\mathrm{CRP}(\mathrm{mg} / \mathrm{dl})$ & $\leq 3.3$ & $\leq 11$ & $\leq 26$ & $>26$ \\
\hline CDAI & $\mathrm{TJC}+\mathrm{SJC}+\mathrm{PGA}(\mathrm{cm})+\mathrm{DGA}(\mathrm{cm})$ & $\leq 2.8$ & $\leq 10$ & $\leq 22$ & $>22$ \\
\hline DAS-28 & $0.56 * \sqrt{\mathrm{TJC}}+0.28 * \sqrt{\mathrm{SJC}}+0.7 * \ln (\mathrm{ESR})+0.014 * \mathrm{PGA}(\mathrm{mm})$ & $\leq 2.6$ & $\leq 3.2$ & $\leq 5.1$ & $>5.1$ \\
\hline
\end{tabular}


Table 4. Synthetic DMARDs

\begin{tabular}{|c|c|c|c|c|c|}
\hline & Indication & Dose & Side-effects & Monitoring & Contraindications \\
\hline \multirow[t]{2}{*}{ MTX } & $\begin{array}{l}\text { First choice } \\
\text { DMARD as } \\
\text { monotherapy } \\
\text { or combination } \\
\text { therapy }\end{array}$ & $\begin{array}{l}7.5 \text { - } 25 \mathrm{mg} \\
\text { weekly orally or } \\
\text { subcutaneously }\end{array}$ & $\begin{array}{l}\text { Common: nausea and } \\
\text { vomiting, mucositis, } \\
\text { alopecia, elevated liver } \\
\text { enzymes, anaemia, } \\
\text { neutropenia }\end{array}$ & $\begin{array}{l}\text { Baseline CXR; full } \\
\text { blood count and liver } \\
\text { transaminase test within } \\
\text { the first month of } \\
\text { treatment, and thereafter } \\
3 \text { - 6-monthly }\end{array}$ & $\begin{array}{l}\text { Pregnancy and breast- } \\
\text { feeding, alcoholism, } \\
\text { liver disorders, renal } \\
\text { failure, bone marrow } \\
\text { suppression, interstitial } \\
\text { lung disease }\end{array}$ \\
\hline & $\begin{array}{l}\text { Co-prescribed } \\
\text { with biologic } \\
\text { drugs }\end{array}$ & $\begin{array}{l}\text { Co-prescribe with } \\
\text { folic acid } 5-10 \\
\text { mg/week, } 24 \text { hrs } \\
\text { after MTX }\end{array}$ & $\begin{array}{l}\text { Less frequent: pneumonitis, } \\
\text { teratogenic }\end{array}$ & & $\begin{array}{l}\text { Caution in HIV-positive } \\
\text { patients }\end{array}$ \\
\hline CQ & $\begin{array}{l}\text { Mild RA or } \\
\text { as part of } \\
\text { combination } \\
\text { therapy }\end{array}$ & $\begin{array}{l}4 \mathrm{~g} / \mathrm{kg} / \text { day } \\
\text { (generally } 200 \mathrm{mg} 3 \\
\text { - } 5 \text { times per week), } \\
\text { orally }\end{array}$ & $\begin{array}{l}\text { Common: gastrointestinal } \\
\text { intolerance, skin } \\
\text { hyperpigmentation, } \\
\text { headache, dizziness } \\
\text { Less frequent: retinopathy } \\
\text { and myopathy }\end{array}$ & $\begin{array}{l}\text { Annual ophthalmological } \\
\text { assessments }\end{array}$ & \\
\hline SSZ & $\begin{array}{l}\text { Monotherapy } \\
\text { if MTX not } \\
\text { tolerated or } \\
\text { contraindicated, } \\
\text { or as part of } \\
\text { combination } \\
\text { therapy }\end{array}$ & $1-3 \mathrm{~g} /$ day, orally & $\begin{array}{l}\text { Common: gastrointestinal } \\
\text { intolerance (anorexia, } \\
\text { nausea, vomiting), skin } \\
\text { rash, elevated liver } \\
\text { enzymes, myelosuppression }\end{array}$ & $\begin{array}{l}\text { Full blood count and liver } \\
\text { transaminase test within } \\
\text { the first } 1 \text { - } 2 \text { months of } \\
\text { treatment, and thereafter } \\
3 \text { - 6-monthly }\end{array}$ & \\
\hline \multirow[t]{2}{*}{ Leflunomide } & $\begin{array}{l}\text { Monotherapy or } \\
\text { in combination } \\
\text { with MTX }\end{array}$ & $\begin{array}{l}20 \mathrm{mg} / \text { day orally, } \\
\text { but } 20 \mathrm{mg} \text { on } \\
\text { alternate days can } \\
\text { be used }\end{array}$ & $\begin{array}{l}\text { Nausea, vomiting, } \\
\text { abdominal pain, diarrhoea, } \\
\text { alopecia, elevated liver } \\
\text { enzymes, skin rash }\end{array}$ & $\begin{array}{l}\text { Full blood count and } \\
\text { liver transaminase test } \\
\text { within the first month of } \\
\text { treatment, and thereafter } \\
3 \text { - 6-monthly }\end{array}$ & $\begin{array}{l}\text { Pregnancy and breast- } \\
\text { feeding, suspension } \\
\text { is recommended } 2 \\
\text { years before a possible } \\
\text { pregnancy; alternatively, } \\
\text { cholestyramine washout. }\end{array}$ \\
\hline & & & $\begin{array}{l}\text { Teratogenic in both male } \\
\text { and female patients }\end{array}$ & & \\
\hline
\end{tabular}

long-term use, and GCs are not appropriate as monotherapy. Lowdose oral prednisone ( $\leq 10 \mathrm{mg} /$ day) is appropriate in combination with DMARDs in early RA ( $<2$ year disease duration) for up to 6 months, after which the symptomatic effects seem to wane. In established RA, they may be used as 'bridging' therapy when DMARDs are initiated, and should be withdrawn once DMARDs have controlled the disease. ${ }^{[28,29]}$ Intra-articular GCs are useful for a mono- or oligo-articular flare of disease. Long-acting intramuscular methylprednisolone may be used as an alternative to oral prednisone.

\subsection{Biologic DMARDs}

One of the most significant advances in the treatment of RA in recent years has been the development of biologic DMARDs, which are proteins directed against specific cytokines or their cell receptors. A wide choice of biologic DMARDs is now available in SA, with excellent efficacy in controlling RA in patients who have failed synthetic DMARD therapy. Clinical trials and post-marketing experience have shown that these DMARDs treat many aspects of RA disease: suppression of joint inflammation, prevention of radiographic progression, and improvement of physical function and health-related quality of life. ${ }^{[30]}$ They may be classified into those inhibiting tumour necrosis factor (TNF) (i.e anti-TNF), and those targeting other cytokines or cells (non-anti-TNF). The ACR,
EULAR and SARAA have developed recommendations for the use of these agents. ${ }^{[26,31,32]}$ Biologic DMARDs are usually co-prescribed with MTX to improve efficacy and reduce antichimeric antibody production. The use of combination biologic DMARDs is not recommended. Table 5 summarises the biologics currently available, and provides details of dose and administration. Biologic DMARDs should be initiated by a rheumatologist, and information about patients on biologic therapy entered into a SARAA biologics registry.

\subsection{Timing and choice of biologic therapy}

In SA, commencement of biologic therapy after a 6-month trial of at least 3 synthetic DMARDs (including MTX, unless contraindicated) seems reasonable, given resource constraints, and given that up to one-third of patients will achieve LDA on synthetic DMARD therapy ${ }^{[33,34]}$ Indications for biologic therapy include an inadequate response to synthetic DMARD therapy, with high disease activity (SDAI $>26$ ), or moderate disease activity (SDAI $11-26$ ) in the presence of poor prognostic factors (seropositivity, radiographic erosions within the first two years, extra-articular complications or functional disability). The efficacy of all currently available biologic drugs has been confirmed by clinical trials and by clinical experience, and the choice of drug depends on the safety profile 
Table 5. Biologic DMARDs currently available in South Africa

\begin{tabular}{|c|c|c|c|c|c|c|}
\hline & & & & & Half-life (days) & \\
\hline Medication & Target & Type & Route & Dose & $n$ & Special comments \\
\hline Anti-TNF & & & & & & Extensive data from clinical trials and \\
\hline Infliximab & TNF- $\alpha$ & $\begin{array}{l}\text { Mouse/human } \\
\text { chimeric } \\
\text { monoclonal } \\
\text { antibody }\end{array}$ & IV & $\begin{array}{l}3 \mathrm{mg} / \mathrm{kg} \text { every } 8 \\
\text { weeks }\end{array}$ & $8-10$ & $\begin{array}{l}\text { clinical experience; hence used as } \\
\text { first-line biologics in most countries. } \\
\text { Dose adjustment possible. These drugs } \\
\text { confer increased risk of TB. }\end{array}$ \\
\hline Etanercept & TNF- $\alpha$ & $\begin{array}{l}\text { Soluble } \\
\text { receptor fusion } \\
\text { protein }\end{array}$ & $\mathrm{S} / \mathrm{C}$ & $\begin{array}{l}50 \text { mg weekly (or } 25 \\
\text { mg twice weekly) }\end{array}$ & 4 & \\
\hline Adalimumab & TNF- $\alpha$ & $\begin{array}{l}\text { Human } \\
\text { monoclonal } \\
\text { antibody }\end{array}$ & $\mathrm{S} / \mathrm{C}$ & $\begin{array}{l}40 \mathrm{mg} \text { every other } \\
\text { week }\end{array}$ & $10-20$ & \\
\hline \multicolumn{7}{|l|}{ Non-anti-TNF } \\
\hline Abatacept & $\begin{array}{l}\text { T-cell } \\
\text { co-stimulation }\end{array}$ & $\begin{array}{l}\text { Receptor } \\
\text { fusion protein }\end{array}$ & IV & $\begin{array}{l}\text { Weight dependant } \\
500 \mathrm{mg}, 750 \mathrm{mg} \text { or } \\
1000 \mathrm{mg} \text { every } 4 \\
\text { weeks }\end{array}$ & $8-25$ & $\begin{array}{l}\text { Useful where high risk of sepsis. } \\
\text { Useful in heart failure. }\end{array}$ \\
\hline Rituximab & $\mathrm{CD} 20^{+} \mathrm{B}$ cells & $\begin{array}{l}\text { Mouse/human } \\
\text { chimeric } \\
\text { antibody }\end{array}$ & IV & $\begin{array}{l}2 \times 1000 \mathrm{mg} 14 \text { days } \\
\text { apart 6-monthly or } \\
\text { at disease flare }\end{array}$ & $19-22$ & $\begin{array}{l}\text { Useful in seropositive patients. Long } \\
\text { half-life, thus less flexibility if adverse } \\
\text { effects or poor response. }\end{array}$ \\
\hline Tocilizumab & IL-6 receptor & $\begin{array}{l}\text { Humanised } \\
\text { IL- } 6 \text { receptor } \\
\text { antibody }\end{array}$ & IV & $\begin{array}{l}8 \mathrm{mg} / \mathrm{kg} \text { every } 8 \\
\text { weeks }\end{array}$ & 13 & $\begin{array}{l}\text { Useful for IL- } 6 \text { driven disease } \\
\text { anaemia, high CRP, fatigue. }\end{array}$ \\
\hline
\end{tabular}

DMARD = disease modifying anti-rheumatic drug; TNF = tumour necrosis factor; IV = intravenous; $\mathrm{S} / \mathrm{C}=$ subcutaneous; IL = interleukin.

and on the patient's preferred route of administration. At present, the optimal sequence of biologics remains unclear. In future, biomarkers may assist in identifying the most appropriate biologic agent for an individual patient. ${ }^{[35]}$

A biologic DMARD that has not resulted in an adequate clinical response after 6 months of treatment should be withdrawn and another biologic DMARD should be prescribed. ${ }^{[36]}$

\subsection{Analgesics and anti-inflammatory drugs}

Analgesics should be prescribed and taken on an 'as needed' basis for pain control. Nonsteroidal anti-inflammatory drugs (NSAIDs) are effective in controlling pain and stiffness, but are purely symptomatic therapies and offer no disease-modifying action. The toxicity of these drugs should not be underestimated. In RA, NSAIDs are often prescribed on a long-term basis, but should be used with caution as many patients have risk factors for NSAIDinduced gastrointestinal tract events. Particularly at risk are older patients (age $>60$ years), as well as those who are co-prescribed corticosteroids and aspirin. Hence, there should be a low threshold for co-prescribing a proton pump inhibitor for gastroprotection, or for considering a COX-2 selective agent (coxib). ${ }^{[37]}$ In addition, all NSAIDs, both non-selective agents and coxibs, confer an increased risk of thrombotic events, and should be used with caution in patients with cardiovascular risk factors. ${ }^{[38]}$ Other side-effects of NSAIDs, including hypertension, renal and liver dysfunction should not be forgotten. Blood pressure should be checked within a month of initiating NSAID therapy. Ideally, NSAIDs should be used in the lowest effective dose and for the shortest duration of time, and withdrawn if possible once disease activity is controlled with DMARDs.

\subsection{Extra-articular disease}

Moderate to high-dose GCs, possibly combined with other immunosuppressant drugs, are used in severe extra-articular disease including serositis, vasculitis and scleritis.

\subsection{Multidisciplinary team}

Care of the RA patient requires a multidisciplinary approach with referral to an occupational therapist, podiatrist, physiotherapist, clinical psychologist and social worker, as appropriate. A rheumatology nurse can offer patient education and support, with positive effects on adherence to therapy and on health-related quality of life. ${ }^{[39]}$ Adoption of a healthy lifestyle that includes regular exercise, loss of weight if overweight, and discontinuation of smoking is of benefit. Smoking has been shown not only to increase the risk of developing RA, but also to worsen the severity of joint disease, extra-articular complications and comorbidities of RA. ${ }^{[40]}$

Referral of the RA patient for orthopaedic surgery may be appropriate in certain circumstances. Importantly, surgical treatment of RA is only an adjunct to medical control of the disease with DMARDs. With modern aggressive therapy of RA, the number of patients requiring joint replacements and other surgical interventions is declining. ${ }^{[41]}$

\section{Complications and safety issues \\ 6.1 TB}

All RA patients are at increased risk of TB, and this risk is increased by drugs used to treat RA including GCs, MTX and biologic drugs, in particular anti-TNF therapy. ${ }^{[42]}$ The pro-inflammatory cytokine TNF plays an essential role in the containment of mycobacterial infection in granulomas, and inhibition of TNF may lead to reactivation of latent $\mathrm{TB}$, or possibly to new $\mathrm{TB}$ infection. ${ }^{[43]}$ This reactivation of TB generally occurs within the first $3-6$ months of initiation of anti-TNF therapy. 
The presentation may be atypical, with over half of cases reported as extra-pulmonary, and a high proportion of disseminated TB. ${ }^{[44]}$

Prior to initiation of therapy, each patient requires screening for latent TB infection (LTBI), and an assessment of the risk of TB infection/ reactivation (risk stratification).

\subsubsection{Screening for LTBI}

The efficacy of screening for and treatment of LTBI before initiation of anti-TNF therapy has been well demonstrated, but the most appropriate test to detect LTBI is uncertain. ${ }^{[4-46]}$ In a high prevalence setting such as SA, there is no reliable test for LTBI. The tuberculin skin test (TST) has traditionally been the primary tool for identifying LTBI, but limitations include false-negative results in immunocompromised patients (for example patients on immunosuppressive drugs such as MTX or corticosteroids $s^{[47]}$ ) and a false-positive test after BCG vaccination at birth, although this is not believed to be very significant amongst adults. ${ }^{[48]}$ Other problems with the TST are the logistics of return visits for evaluation, and variations in administration and interpretation of the test. ${ }^{[49]}$ Despite this, detection of LTBI by TST (defined as induration $\geq 5 \mathrm{~mm}$ ) is highly effective. Recently, interferon (IFN)- $\gamma$ release assays (IGRAs), which measure IFN- $\gamma$ response to TB-specific antigens, have been introduced. While excellent performance and good cost effectiveness of these tests have been reported, ${ }^{[50]}$ a negative IGRA does not exclude LTBI. In low-prevalence settings, the combination of TST and IGRA may be the best strategy. ${ }^{[51]}$ Currently, there is little consensus on the most appropriate screening test in high-prevalence settings such as SA. ${ }^{[52]}$

A patient due to commence biologic therapy should have a TST, an IGRA test (if deemed appropriate by the clinician), and a CXR. An abnormal CXR suggesting active pulmonary TB clearly needs investigation, and treatment for the patient. A patient with a positive TST, and a normal CXR, should be given anti-TB chemoprophylaxis. Extrapolating from studies in HIV-positive patients, chemoprophylaxis may be either isoniazid (INH) for 9 months, or rifampicin combined with INH for 3 months. ${ }^{[53]}$ The consensus is that anti-TNF therapy can be initiated after completion of a minimum of 1 month of chemoprophylaxis.

\subsubsection{TB risk stratification}

The incidence of TB in SA is amongst the highest in the world, with an estimated incidence of 808 per 100000 in the general population. ${ }^{[54]}$ In light of this, there are valid concerns regarding the safety of anti-TNF drugs, and all patients must be considered to be at relatively high risk of TB. In the absence of prospective data, recommendations must err on the side of caution.

The risk of developing active $\mathrm{TB}$ in RA patients treated with biologic DMARDs appears to depend on the background prevalence of LTBI. Factors associated with LTBI in the USA and in Hong Kong include older age, residence or travel in a TB-endemic area, high-risk occupation (healthcare or institution worker), previous TB infection, Felty's syndrome, and low socio-economic status. ${ }^{[55,56]}$ Concomitant corticosteroid use and monoclonal rather than soluble anti-TNF drugs seem to confer a higher risk for TB. ${ }^{[4,57,58]}$ Non-anti-TNF therapy appears to confer a much lower risk of TB, but cases have been reported. ${ }^{[59]}$

\subsubsection{Very high-risk patients}

Patients who are stratified as being at very high risk of LTBI and who require biologic therapy need careful consideration. This stratification is left to the physician's discretion, but would include healthcare workers, inmates or employees at institutions, patients who have had previous TB or who have a poor socio-economic background.

If such a high-risk patient is to commence anti-TNF therapy, a strategy offering 9 months of INH prophylaxis, regardless of TST/
IGRA result, may be appropriate. Such a policy has been adopted in India because of the high incidence of TB. ${ }^{[60]}$ Despite concerns of INH toxicity and of propagating INH-resistant $\mathrm{TB}$, this strategy may be valid in high-risk settings such as SA. Longer-term chemoprophylaxis, continued for the duration of anti-TNF therapy, may be appropriate in very high-risk patients, but there are no prospective data.

Alternatively, non-anti-TNF drugs may be the safest choice of firstline biologic therapy in such patients. This is the current practice in Algeria and Morocco, and has been shown to be effective in high-risk patients in Germany. ${ }^{[1,62]}$

\subsection{Other infections}

There is an increased risk of infection amongst RA patients, particularly in patients treated with biologic therapy ${ }^{[30]}$ These include serious bacterial infections, as well as opportunistic fungal (histoplasmosis in particular), Listeria and non-tuberculous mycobacterial infections. Hence, biologic drugs should be used with caution in patients with chronic infected leg ulcers, septic arthritis in the preceding 12 months, septic arthritis of prosthetic joints, recurrent urinary or respiratory tract infections, an indwelling urinary catheter, or hypogammaglobulinaemia.

In the presence of active infection, administration of a biologic drug should be delayed. MTX does not increase the risk of sepsis or peri-operative complications in patients undergoing joint replacement surgery, and can be continued. ${ }^{[63]}$ There may be a small risk of perioperative infections in patients using biologic DMARDs, and it is recommended that these drugs are discontinued prior to surgery for a period of 3 - 5 times the half-life of the drug, and resumed after good wound healing.

\subsection{HIV infection}

In SA, the burden of HIV infection is amongst the highest in the world, with an estimated $33 \%$ of females between the ages of 25 and 29 years infected in 2010. ${ }^{[64]}$ This pandemic has both diagnostic and therapeutic implications for the management of patients with concomitant inflammatory arthritis. ${ }^{[65]}$

HIV infection can cause, among other musculoskeletal syndromes, inflammatory polyarthritis mimicking RA. ${ }^{[6]]}$ Hence, an HIV test may be appropriate in a patient presenting with inflammatory arthritis.

There are several challenges in the management of RA patients who are HIV-positive. Information on the safety of using immunosuppressive drugs in an HIV-positive patient is limited. MTX and biologic drugs place patients at risk of opportunistic infections, and there is concern of added immunosuppression if prescribed in an HIV-positive patient. ${ }^{[67]}$ For this reason, these therapies are not recommended and CQ (which may have antiviral properties ${ }^{[68]}$ ) or SSZ may be more appropriate choices. In addition, there are difficulties in the assessment of disease activity in HIV-positive patients due to the nonspecific increase in erythrocyte sedimentation rate (ESR) associated with HIV infection. ${ }^{[69]}$ Little is known about the effect of antiretroviral therapy (ART) on RA disease, or the safety of biologic drugs in patients receiving ART. These are areas for future research.

\subsection{Viral hepatitis}

Hepatitis B reactivation can occur in hepatitis B surface antigen (HBsAg)positive patients treated with MTX or biologic therapy (particularly rituximab). Thus, screening for viral hepatitis before starting treatment in high-risk patients is recommended ${ }^{[70]}$ Hepatitis B vaccination should ideally be offered to non-immune patients before commencing DMARD treatment. In hepatitis C-infected patients, anti-TNF therapy and rituximab is considered safe, and possibly beneficial. ${ }^{[71]}$ 


\subsection{Vaccination}

Patients with RA should receive killed vaccines based on age and risk, ideally at least 14 days before commencing DMARD or biologic therapy for optimal efficacy. These might include influenza, pneumococcal, hepatitis B and human papillomavirus vaccines. Live vaccines including herpes zoster and yellow fever vaccines are not recommended in RA patients on MTX or biologic therapy. It may, however, be appropriate to vaccinate a patient likely to travel to a high-risk yellow fever area, prior to commencing biologic therapy.

\subsection{Cardiovascular events}

Due to a combination of systemic inflammation and traditional cardiovascular risk factors, patients with RA have increased cardiovascular disease and risk of cardiovascular death, similar to that seen in patients with type 2 diabetes. ${ }^{[72]}$ Traditional risk factors including smoking, hypertension, diabetes mellitus, and dyslipidaemia (most importantly low levels of high-density lipoprotein (HDL) cholesterol and resultant high total cholesterol to HDL ratio) need to be addressed. ${ }^{[73]}$ In SA, treatment of dyslipidaemia is based on cardiovascular risk estimation using the Framingham Risk Score. ${ }^{[74]}$ In the setting of RA that is seropositive, extra-articular or established ( $\geq 10$ year disease duration), this percentage risk should be multiplied by $1.5 .^{[73]}$

Uncontrolled severe joint inflammation, extra-articular disease, physical inactivity and corticosteroid use further contribute to the risk of cardiovascular events. ${ }^{[75]}$ Improved disease control with therapy, such as MTX and anti-TNF therapy, has been shown to decrease cardiovascular risk in RA patients. ${ }^{[7,77]}$

\subsection{Osteoporosis}

Bone loss is an important consequence of long-standing RA, and patients may require co-therapy with osteoclast-inhibiting agents or osteoblast stimulators. The pathogenesis of osteoporosis in RA is multi-factorial and can be cumulative over time. In early disease, the predominant feature is localised, or juxta-articular, osteoporosis, which is a consequence of locally acting pro-inflammatory cytokines. It is not yet clear whether biologic DMARDs are capable of retarding or reversing bone loss in RA, but studies are under way to evaluate this. One recent study ${ }^{[78]}$ failed to show a significant impact on bone density following anti-TNF therapy, but the sample size and duration may have meant that it was under-powered.

Generalised osteoporosis affecting the femur and lumbar spine is usually seen in long-standing RA, especially in post-menopausal women. The mechanism is likely to be due to a combination of immobilisation, age, menopause, GC therapy and inflammation due to RA. The dose of prednisone associated with bone loss is likely to be as low as $2.5 \mathrm{mg}$ daily. ${ }^{[79]}$ The ACR has recently published revised guidelines for the treatment of GC-induced osteoporosis, recommending that a lower threshold for intervention be used, since fractures in these patients may occur when the bone mineral density T-score is $>-2.5$ but $<-1.0 .{ }^{[80]}$ Calcium and vitamin $\mathrm{D}$ supplementations are recommended for routine use in all patients likely to receive GC therapy for longer than 6 months, irrespective of dose. Control of joint inflammation with DMARD therapy will help to maintain the bone density by improving physical activity.

\subsection{Malignancy}

Patients with RA are at increased risk of lymphoma, with the major risk being uncontrolled joint inflammation rather than DMARD therapy ${ }^{[81]}$ Neither synthetic nor biologic DMARDs seem to confer an increased risk of malignancy, ${ }^{[82,83]}$ nor do they increase the chance of recurrence of a malignancy, or change the prognosis of cancers that occur in patients using biologic therapies. ${ }^{[84]}$ The current recommendations are that biologic therapy be avoided in patients with a current or recent ( $<5$ years) diagnosis of a malignancy.

\subsection{Pregnancy}

RA tends to improve during pregnancy. In general, because of potential risks to the fetus, DMARDs are not recommended, and low-dose GCs may be adequate to control symptoms. MTX and leflunomide are contraindicated in pregnancy and breastfeeding, but SSZ and CQ are considered relatively safe and may be useful in active disease. There is sparse evidence for the safety of biologic drugs in pregnancy or lactation and formal recommendations are that anti-TNF drugs and rituximab be stopped 3 months and 12 months, respectively, before conception. However, there are recent reports of successful pregnancies in patients using anti-TNF drugs, and many experts feel that these drugs can be safely continued during conception and the first 2 trimesters of pregnancy. ${ }^{[85]}$

\section{Monitoring patients on therapy}

Disease activity should be evaluated with an SDAI, and an intensive disease control strategy should be used with escalation of therapy if LDA or, ideally, remission is not achieved. Patients with moderate or high disease activity should be assessed frequently (1 - 3-monthly) until an LDA state is achieved, after which less frequent visits (3 - 6-monthly) are acceptable.

Monitoring for toxicity of DMARD therapy is summarised in Table 4. There is no indication for 'routine' liver biopsy in patients on MTX therapy. A biopsy may be indicated in a patient with persistently elevated liver enzymes ( $>3$ times the upper level of normal) after DMARD discontinuation. ${ }^{\left[{ }^{[6]}\right.}$ Annual serum creatinine and cholesterol tests are appropriate. Baseline bone mineral density measurements are recommended in post-menopausal women starting long-term GC therapy and should be repeated at 5-yearly intervals.

Because of the high risk of infection, including TB, RA patients and their physicians must remain vigilant for symptoms of infection. Patients should be advised to seek medical attention for any symptoms of possible infection, to allow for prompt assessment and treatment. Loss of weight, fever or lymphadenopathy in a patient on biologic therapy requires prompt investigation for $\mathrm{TB}$, which might include a CXR, abdominal ultrasound and bone marrow aspiration.

\section{SA rheumatologist survey}

An online survey was sent to all SA rheumatologists to assess the level of agreement with 9 statements on management of RA. Rheumatologists were asked to score their agreement with each statement on a 10-point numerical scale $(10=$ agree completely; $0=$ do not agree at all). The response rate to the survey was $46 / 81$ (57\%), and results are shown in Table 6. Importantly, there was strong support for an intensive control strategy involving frequent (1 - 3-monthly) visits, and calculation of a composite disease activity index with escalation of therapy if LDA is not achieved. In addition, there was excellent agreement regarding the selection of patients for biologic therapy. Of interest, the vast majority $(83 \%)$ of SA rheumatologists concur that in patients at high risk of TB, non-TNF biologic therapy may be the more appropriate first-line therapy. There was moderate agreement (64\%) with an approach giving INH prophylaxis to all high-risk patients starting anti-TNF treatment.

\section{Economic aspects of therapy}

The costs of therapy to treat RA, which may include the considerable expense of biologic drugs in patients who do not respond to synthetic DMARDs alone, need to be balanced against the consequences of uncontrolled disease with ensuing joint damage and disability. Loss of productivity in the home and workplace, loss of income, isolation from 
Table 6. Level of agreement for online survey on issues of RA therapy sent to all SA rheumatologists $(N=46)^{\star}$

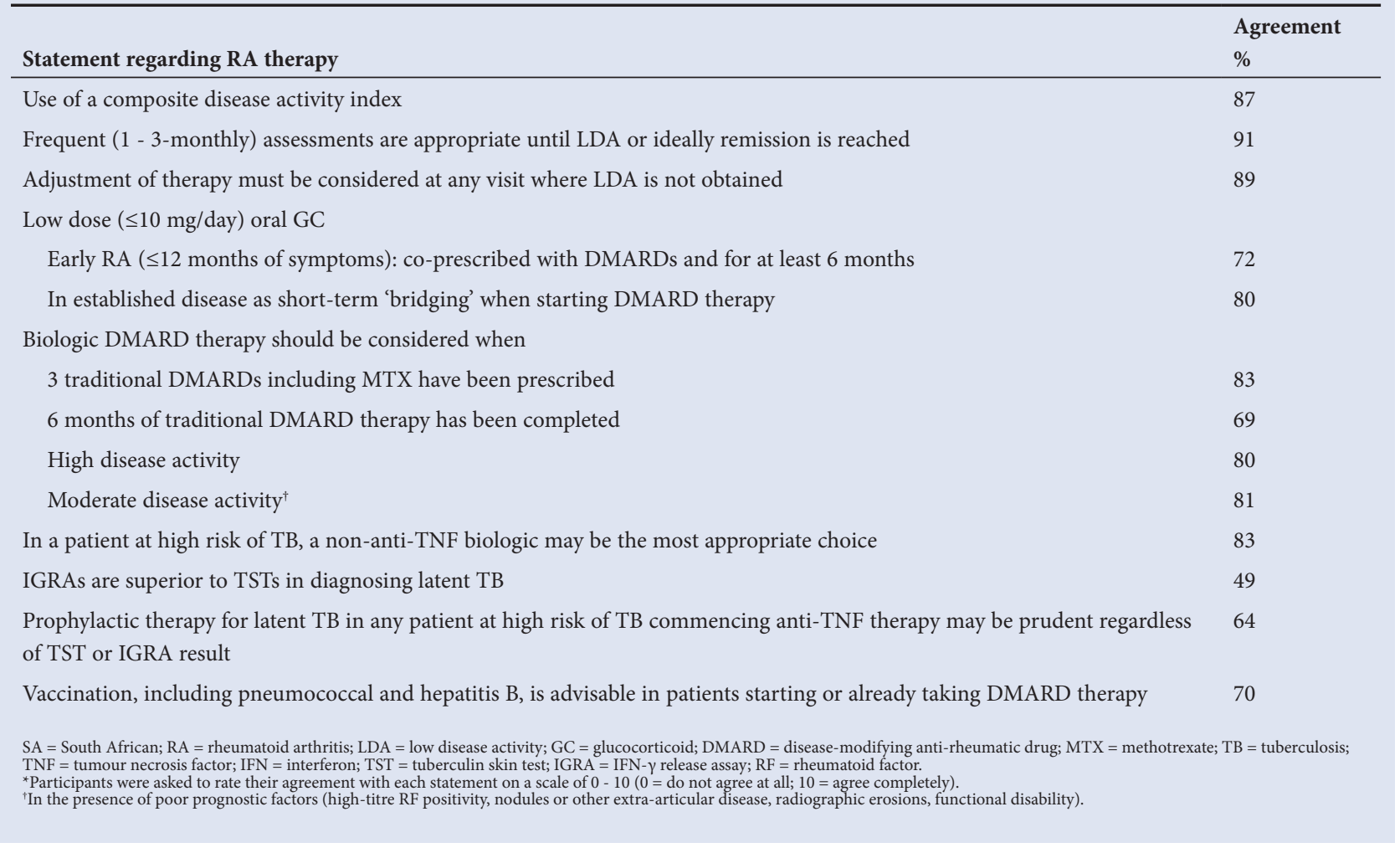

society and reduced recreational comforts, together with the negative psychosocial impact of the disease, have severe economic consequences for patients, their families, and to society. ${ }^{[87]}$ The measures used to quantify these effects include the disability adjusted life-years (DALY) and the quality of life-years lost (QALY).

The costs of therapy will be relatively low in patients receiving nonbiologic DMARDs, but will escalate when biologic DMARDs are added. When comparing different therapies for the treatment of RA, the number needed to treat (NNT) to achieve a response may be a useful reference. Such calculations will differ, depending on the tool used to measure response. Most studies base their calculations on achieving an ACR 50 response in a $70 \mathrm{~kg}$ subject. A recent meta-analysis of the cost-effectiveness of all biologics showed that the NNT varied between 2.8 and 5.7..$^{[88]}$

A recent systematic review of the literature, which contributed to the EULAR recommendations, showed that the merits of effective control of RA outweigh the costs of therapy ${ }^{[89]}$ At disease onset, synthetic DMARDs should be initiated. If these fail, treatment escalations with biologic therapy are cost-effective, provided standard dosing schemes are used.

\section{Areas for future research}

There are several areas for future research to provide answers to optimal RA management in our unique SA situation. The most important issues revolve around TB, including the safety of biologic DMARDs, and the risk factors for development of TB. Contemporary epidemiological data on the prevalence and incidence of RA in SA are needed. Other areas for investigation include management of RA in HIV-positive patients, the burden of RA on productivity in SA, and local exploration of the cost-effectiveness of RA treatment.

Due to recent advances in RA therapies, it is suggested that these recommendations are updated every 2 years.

In summary, effective management of RA requires prompt diagnosis, early initiation of DMARD therapy, and an intensive control strategy with frequent assessments and rapid escalation of therapy. The aim should be to achieve LDA or ideally remission. Biologic drugs should be considered in patients who have shown inadequate response to synthetic DMARDs.

Acknowledgements. The authors gratefully acknowledge Abbott Laboratories for facilitating the meetings to draw up these recommendations.

\section{References}

1. Alamanos Y, Voulgari PV, Drosos AA. Incidence and prevalence of rheumatoid arthritis, based on the 1987 American College of Rheumatology criteria: A systematic review. Semin Arthritis Rheum 2006;36(3):182-188. [http://dx.doi.org/10.1016/j.semarthrit.2006.08.006]

2. Solomon L, Robin G, Valkenburg HA. Rheumatoid arthritis in an urban South African Negro population. Ann Rheum Dis 1975;34(2):128-135. [http://dx.doi.org/10.1136/ard.34.2.128]

3. Wolfe F. 50 years of anti-rheumatic therapy: The prognosis of rheumatoid arthritis. J Rheumatol (Suppl) 1990;22:24-32.
. Wolfe F. 50 years of

4. Anderson JJ, Wells G, Verhoeven AC, et al. Factors predicting response to treatment in rheumatoid arthritis: 4. Anderson ]J, Wells G, Verhoeven AC, et al. Factors predicting response to treatment in rheumatoid arthritis:
The importance of disease duration. Arthritis Rheum 2000;43(1):22-29. [http://dx.doi.org/10.1002/15290131(200001)43:1<22::AID-ANR4 $>3.0 . C O ; 2-9$ ]

5. Hulsmans HM, Jacobs JW, van der Heijde DM, et al. The course of radiologic damage during the first six years of rheumatoid arthritis. Arthritis Rheum 2000;43(9):1927-1940. [http://dx.doi.org/10.1002/15290131(200009)43:9<1927::AID-ANR3>3.0.CO;2-B]

6. O'Dell JR. How is it best to treat early rheumatoid arthritis patients? Best Pract Res Clin Rheumatol 2001;15(1):125-137. [http://dx.doi.org/10.1053/berh.2000.0130]

. Nell VP, Machold KP, Eberl G, et al. Benefit of very early referral and very early therapy with disease-modifying anti-rheumatic drugs in patients with early rheumatoid arthritis. Rheumatology 2004;43(7):906-914. [http://dx.doi.org/10.1093/rheumatology/keh199]

8. Aletaha D, Neogi T, Silman AJ, et al. 2010 Rheumatoid arthritis classification criteria: An American College of Rheumatology/European League Against Rheumatism collaborative initiative. Arthritis Rheum 2010;62(9):2569-2581. [http://dx.doi.org/10.1002/art.27584]

9. Arnett FC, Edworthy SM, Bloch DA, et al. The American Rheumatism Association 1987 revised criteria 9. Arnett FC, Edworthy SM, Bloch DA, et al. The American Rheumatism Association 1987 revised criteria
for the classification of rheumatoid arthritis. Arthritis Rheum 1988;31(3):315-324. [http://dx.doi. org/10.1002/art.1780310302]

10. Arthritis Care. Have you got the $S$ factor? http://www.arthritiscare.org.uk/AboutArthritis/HaveyougottheSfactor (accessed 13 May 2013).

11. Beattie KA, MacIntyre NJ, Cividino A. Screening for signs and symptoms of rheumatoid arthritis by family physicians and nurse practitioners using the Gait, Arms, Legs, and Spine musculoskeletal examination. Arthritis Care Res 2012;64(12):1923-1927. [http://dx.doi.org/10.1002/acr.21740]

12. van der Heijde DM, van't Hof MA, van Riel PL, Van de Putte L. Disease activity score. Ann Rheum Dis 1992;51(1):140.

13. Aletaha D, Smolen J. The Simplified Disease Activity Index (SDAI) and the Clinical Disease Activity Index (CDAI): A review of their usefulness and validity in rheumatoid arthritis. Clin Exp Rheumatol 2005;23(5):S100-S108.

14. Aletaha D, Nell VP, Stamm T, et al. Acute phase reactants add little to composite disease activity indices for rheumatoid arthritis: Validation of a clinical activity score. Arthritis Res Ther 2005;7(4):R796-R806.

15. Smolen JS, Aletaha D. The assessment of disease activity in rheumatoid arthritis. Clin Exp Rheumatol 2010;28(3):S18-S27. 
16. Felson DT, Anderson JJ, Boers M, et al. American College of Rheumatology preliminary definition of improvement in rheumatoid arthritis. Arthritis Rheum 1995;38(6):727-735. [http://dx.doi.org/10.1002/ art.1780380602]

17. Knevel R, Schoels M, Huizinga TW, et al. Current evidence for a strategic approach to the management of rheumatoid arthritis with disease-modifying anti-rheumatic drugs: A systematic literature review informing the EULAR recommendations for the management of rheumatoid arthritis. Ann Rheum Dis 2010;69(6):987-994. [http://dx.doi.org/10.1136/ard.2009.126748]

18. Kirwan JR, Reeback JS. Stanford Health Assessment Questionnaire modified to assess disability in British patients with rheumatoid arthritis. Br J Rheumatol 1986;25(2):206-209. [http://dx.doi.org/10.1093/ rheumatology/25.2.206]

19. Hazes JM. Determinants of physical function in rheumatoid arthritis: Association with the disease process. Rheumatology 2003;42(S2):ii17-ii21. [http://dx.doi.org/10.1093/rheumatology/keg328]

20. Scott DL, Smith C, Kingsley G. Joint damage and disability in rheumatoid arthritis: An updated systematic review. Clin Exp Rheumatol 2003;21(5):S20-S27.

21. Gossec L, Dougados M, Goupille P, et al. Prognostic factors for remission in early rheumatoid arthritis: A multiparameter prospective study. Ann Rheum Dis 2004;63(6):675-680. [http://dx.doi.org/10.1136/ ard.2003.010611]

22. Wakefield RJ, Kong KO, Conaghan PG, et al. The role of ultrasonography and magnetic resonance imaging in early rheumatoid arthritis. Clin Exp Rheumatol 2003;21(5):S42-S49.

23. Hammer HB, Haavardsholm EA. Advances in imaging. Curr Opin Rheumatol 2012;24(3):299-305. [http://dx.doi.org/10.1097/BOR.0b013e3283521c90]

24. Yazici Y, Erkan D, Paget SA. Monitoring methotrexate hepatic toxicity in rheumatoid arthritis: Is it time to update the guidelines? J Rheumatol 2002;29(8):1586-1589.

25. Salliot C, van der Heijde D. Long-term safety of methotrexate monotherapy in patients with rheumatoid arthritis: A systematic literature research. Ann Rheum Dis 2009;68(7):1100-1104. [http://dx.doi. org/10.1136/ard.2008.093690]

26. Kalla AA, Stanwix A, Gotlieb D, et al. Rheumatoid arthritis: Clinical guideline 2003. S Afr Med J 2003;93(12):991-1012

27. Kirwan JR, Bijlsma JW, Boers M, et al. Effects of glucocorticoids on radiological progression in rheumatoid arthritis. Cochrane Database Syst Rev 2007(1):CD006356. [http://dx.doi.org/10.1002/14651858.CD006356]

28. Mouterde G, Dernis E, Ruyssen-Witrand A, et al. Indications of glucocorticoids in early arthritis and rheumatoid arthritis: Recommendations for clinical practice based on data from the literature and expert rheumatoid arthritis: Recommendations for clinical practice based on data from the literature and
opinion. Joint Bone Spine 2010;77(6):597-603. [http://dx.doi.org/10.1016/j.jbspin.2009.12.011]

29. Gorter SL, Bijlsma JW, Cutolo M, et al. Current evidence for the management of rheumatoid arthritis with gorter SL, Bijlsma JW, Cutolo M, et al. Current evidence for the management of rheumatoid arthritis with glucocorticoids: A systematic literature review informing the EULAR recommendations for the management
of rheumatoid arthritis. Ann Rheum Dis 2010;69(6):1010-1014. [http://dx.doi.org/10.1136/ard.2009.127332]

30. Horton S, Buch MH, Emery P. Efficacy, tolerability and safety of biologic therapy in rheumatoid disease: Patient considerations. Drug Healthc Patient Saf 2010;2:101-119.

31. Singh JA, Furst DE, Bharat A, et al. 2012 update of the 2008 American College of Rheumatology recommendations for the use of disease-modifying anti-rheumatic drugs and biologic agents in the treatment of rheumatoid arthritis. Arthritis Care Res 2012;64(5):625-639. [http://dx.doi.org/10.1002/acr.21641]

32. Smolen JS, Landewe R, Breedveld FC, et al. EULAR recommendations for the management of rheumatoid arthritis with synthetic and biological disease-modifying anti-rheumatic drugs. Ann Rheum Dis 2010;69(6):964-975. [http://dx.doi.org/10.1136/ard.2009.126532]

33. Hodkinson B, Ally M, Musenge E, et al. Response to traditional disease-modifying anti-rheumatic drugs in indigent South Africans with early rheumatoid arthritis. Clin Rheumatol 2012;31(4):613-619. [http://dx.doi. org/10.1007/s10067-011-1900-5

34. Khanna D, Oh M, Furst DE, et al. Evaluation of the preliminary definitions of minimal disease activity and remission in an early seropositive rheumatoid arthritis cohort. Arthritis Rheum 2007;57(3):440-447. [http://dx.doi.org/10.1002/art.22619]

35. Isaacs JD, Ferraccioli $G$. The need for personalised medicine for rheumatoid arthritis. Ann Rheum Dis 2012;70(1):4-7. [http://dx.doi.org/10.1136/ard.2010.135376]

36. Reynolds A, Koenig AS, Bananis E, et al. When is switching warranted among biologic therapies in rheumatoid arthritis? Expert Rev Pharmacoecon Outcomes Res 2012;12(3):319-333. [http://dx.doi. org/10.1586/erp.12.27]

37. Chan FK, Abraham NS, Scheiman JM, et al. Management of patients on nonsteroidal anti-inflammatory drugs: A clinical practice recommendation from the First International Working Party on Gastrointestinal
and Cardiovascular Effects of Nonsteroidal Anti-inflammatory Drugs and Anti-platelet Agents. Am J Gastroenterol 2008;103(11):2908-2918. [http://dx.doi.org/10.1111/j.1572-0241.2008.02200.x]

38. McGettigan P, Henry D. Cardiovascular risk and inhibition of cyclooxygenase: A systematic review of the observational studies of selective and nonselective inhibitors of cyclooxygenase 2. JAMA 2006;296(13):1633-1644. [http://dx.doi.org/10.1001/jama.296.13.jrv60011]

39. Hill J. Rheumatology nurse specialists - do we need them? Rheumatology 2007;46(3):379-381. [http:// dx.doi.org/10.1093/rheumatology/kel431]

40. Baka Z, Buzas E, Nagy G. Rheumatoid arthritis and smoking: Putting the pieces together. Arthritis Res Baka Z, Buzas E, Nagy G. Rheumatoid arthritis and smol
Ther 2009;11(4):238. [http://dx.doi.org/10.1186/ar2751]

41. Skytta E, Honkanen P, Eskelinen A, et al. Fewer and older patients with rheumatoid arthritis need total knee replacement. Scand J Rheumatol 2012;41(5):345-349. [http://dx.doi.org/10.3109/03009742.2012.681061]

42. Baronnet $\mathrm{L}$, Barnetche $\mathrm{T}$, Kahn V, et al. Incidence of tuberculosis in patients with rheumatoid arthritis. A systematic literature review. Joint Bone Spine 2011;78(3):279-284. [http://dx.doi.org/10.1016/j. jbspin.2010.12.004

43. Gardam MA, Keystone EC, Menzies R, et al. Anti-tumour necrosis factor agents and tuberculosis risk: Mechanisms of action and clinical management. Lancet Infect Dis 2003;3(3):148-155. [http://dx.doi. org/10.1016/S1473-3099(03)00545-0]

44. Winthrop KL, Siegel JN, Jereb J, et al. Tuberculosis associated with therapy against tumor necrosis factor $\alpha$. Arthritis Rheum 2005;52(10):2968-2974. [http://dx.doi.org/10.1002/art.21382]

45. Carmona L, Gomez-Reino JJ, Rodriguez-Valverde V, et al. Effectiveness of recommendations to prevent reactivation of latent tuberculosis infection in patients treated with tumor necrosis factor antagonists. Arthritis Rheum 2005;52(6):1766-1772. [http://dx.doi.org/10.1002/art.21043]

46. Dixon WG, Hyrich KL, Watson KD, et al. Drug-specific risk of tuberculosis in patients with rheumatoid Dixon WG, Hyrich KL, Watson KD, et al. Drug-specific risk of tuberculosis in patients with rheumatoid
arthritis treated with anti-TNF therapy: Results from the British Society for Rheumatology Biologics arthritis treated with anti-TNF therapy: Results from the British Society for Rheumatology Biologis
Register (BSRBR). Ann Rheum Dis 2009;69(3):522-528. [http://dx.doi.org/10.1136/ard.2009.118935]

Register (BSRBR). Ann Rheum Dis 2009;69(3):522-528. [http://dx.doi.org/10.1136/ard.2009.118935]
47. Jasmer RM, Nahid P, Hopewell PC. Latent tuberculosis infection. N Engl J Med 2002;347(23):18601866. [http://dx.doi.org/10.1056/NEJMcp021045]

48. Menzies R, Vissandjee B. Effect of bacille Calmette-Guerin vaccination on tuberculin reactivity. Am Rev Respir Dis 1992;145(3):621-625. [http://dx.doi.org/10.1164/ajrccm/145.3.621]

49. Pouchot J, Grasland A, Collet C, et al. Reliability of tuberculin skin test measurement. Ann Intern Med 1997;126(3):210-214. [http://dx.doi.org/10.7326/0003-4819-126-3-199702010-00005]

50. Dheda K, Udwadia ZF, Huggett JF, et al. Utility of the antigen-specific interferon- $\gamma$ assay for the management of tuberculosis. Curr Opin Pulm Med 2005;11(3):195-202.

51. Pooran A, Booth H, Miller RF, et al. Different screening strategies (single or dual) for the diagnosis of suspected latent tuberculosis: A cost effectiveness analysis. BMC Pulm Med 2010;10:7. [http://dx.doi. org/10.1186/1471-2466-10-7]

52. Denkinger CM, Dheda K, Pai M. Guidelines on interferon- $\gamma$ release assays for tuberculosis infection: Concordance, discordance or confusion? Clin Microbiol Infect 2011;17(6):806-814. [http://dx.doi.
Contion Concordance, discordance or confus
org/10.1111/j.1469-0691.2011.03555.x]

53. Martinson NA, Barnes GL, Moulton LH, et al. New regimens to prevent tuberculosis in adults with HIV infection. N Engl J Med 2011;365(1):11-20. [http://dx.doi.org/10.1056/NEJMoa1005136]
54. World Health Organization. South African Tuberculosis Profile 2011. http://www.doh.gov.za/docs/ stats/2011/SouthAfricanTuberculosisProfile2011WHO.pdf (accessed 13 May 2013).

55. American Thoracic Society. Targeted tuberculin testing and treatment of latent tuberculosis infection. Am J Respir Crit Care Med 2000;161:S221-S247. [http://dx.doi.org/10.1164/ajrccm.161.supplement_3.ats600]

56. Tam LS, Leung CC, Ying SK, et al. Risk of tuberculosis in patients with rheumatoid arthritis in Hong Kong - the role of TNF blockers in an area of high tuberculosis burden. Clin Exp Rheumatol 2010;28(5):679-685. 57. Tubach F, Salmon D, Ravaud P, et al. Risk of tuberculosis is higher with anti-tumor necrosis factor monoclonal antibody therapy than with soluble tumor necrosis factor receptor therapy: The threeyear prospective French research axed on tolerance of biotherapies registry. Arthritis Rheum 2009;60(7):1884-1894. [http://dx.doi.org/10.1002/art.24632]

58. Wallis RS. Biologics and infections: Lessons from tumor necrosis factor blocking agents. Infect Dis Clin North Am 2011;25(4):895-910. [http://dx.doi.org/10.1016/j.idc.2011.08.002]

59. Nam JL, Winthrop KL, van Vollenhoven RF, et al. Current evidence for the management of rheumatoid arthritis with biological disease-modifying anti-rheumatic drugs: A systematic literature review 986. [http://dx.doi.org/10.1136/ard.2009.126573]

60. Handa R, Misra R, Chaturvedi VP, et al. Guidelines for tuberculosis prophylaxis during anti-tumou necrosis factor- $\alpha$ treatment: Indian Rheumatology Association. APLAR J Rheumatology 2006;9:181-183. [http://dx.doi.org/10.1111/j.1479-8077.2006.00181.x]

61. El Maghraoui A, Benbouzza K, Bezza A, et al. Recommandations de la Société Marocaine de Rhumatologie pour la prise en charge de la polyarthrite rhumatoïde. XVII Congres National de Rhumatologie, 2007.

62. Xanthouli P, Sailer S, Fiehn C. Rituximab (RTX) as an alternative to TNF- $\alpha$ antagonists in patients with rheumatoid arthritis and high risk of severe infections: A systematic analysis of the experience in one center. Open Rheumatol J 2012;6(1):286-289. [http://dx.doi.org/10.2174/1874312901206010286]

63. Grennan DM, Gray J, Loudon J, et al. Methotrexate and early postoperative complications in patient with rheumatoid arthritis undergoing elective orthopaedic surgery. Ann Rheum Dis 2001;60(3):214217. [http://dx.doi.org/10.1136/ard.60.3.214]

64. Rehle TM, Hallett TB, Shisana O, et al. A decline in new HIV infections in South Africa: Estimating HIV incidence from three national HIV surveys in 2002, 2005 and 2008. PLoS One 2010;5(6):el1094. [http://dx.doi.org/10.1371/journal.pone.0011094]

65. Tikly M. The scourge of HIV infection in sub-Saharan Africa - a rheumatological perspective. J Rheumatol 2011;38(6):973-974. [http://dx.doi.org/10.3899/jrheum.110119]

66. Mody GM, Parke FA, Reveille JD. Articular manifestations of human immunodeficiency virus infection. Best Pract Res Clin Rheumatol 2003;17(2):265-287. [http://dx.doi.org/10.1016/S1521-6942(03)00003-2]

67. McLean-Tooke A, Aldridge C, Waugh S, Spickett GP, Kay L. Methotrexate, rheumatoid arthritis and infection risk: What is the evidence? Rheumatology 2009;48(8):867-871. [http://dx.doi.org/10.1093/ rheumatology/kep101]

68. Paton NI, Aboulhab J. Hydroxychloroquine, hydroxyurea and didanosine as initial therapy for HIV-infected patients with low viral load: Safety, efficacy and resistance profile after 144 weeks. HIV Med 2005;6(1):13-20 [http://dx.doi.org/10.1111/j.1468-1293.2005.00259.x]

69. Ndakotsu MA, Salawu L, Durosinmi MA. Relation between erythrocyte sedimentation rate, clinical and immun status in HIV-infected patients. Niger J Med 2009;18(2):208-210. [http://dx.doi.org/10.4314/njm.v18i2.45067]

70. Vigano M, Degasperi E, Aghemo A, et al. Anti-TNF drugs in patients with hepatitis B or C viru infection: Safety and clinical management. Expert Opin Biol Ther 2012;12(2):193-207. [http://dx.doi. org $/ 10.1517 / 14712598.2012 .646986]$

1. Ferri C, Govoni M, Calabrese L. The A, B, Cs of viral hepatitis in the biologic era. Curr Opin Rheumatol 2010;22(4):443-450. [http://dx.doi.org/10.1097/BOR.0b013e328338f6df]

72. Peters MJ, van Halm VP, Voskuyl AE, et al. Does rheumatoid arthritis equal diabetes mellitus as an independent risk factor for cardiovascular disease? A prospective study. Arthritis Rheum 2009;61(11):1571-1579. [http:// dx.doi.org/10.1002/art.24836]

73. Peters MJ, Symmons DP, McCarey D, et al. EULAR evidence-based recommendations for cardiovascula risk management in patients with rheumatoid arthritis and other forms of inflammatory arthritis. Ann Rheum Dis 2012;69(2):325-331. [http://dx.doi.org/10.1136/ard.2009.113696]

74. Klug E. South African dyslipidaemia guideline consensus statement. S Afr Med J 2012;102(3):178-187. Gabriel SE, Crowson CS. Risk factors for cardiovascular disease in rheumatoid arthritis. Curr Opi Rheumatol 2012;24(2):171-176. [http://dx.doi.org/10.1097/BOR.0b013e32834ff2fd]

76. Westlake SL, Colebatch AN, Baird J, et al. The effect of methotrexate on cardiovascular disease in patient with rheumatoid arthritis: A systematic literature review. Rheumatology 2010;49(2):295-307. [http://dx.do org/10.1093/rheumatology/kep366]

77. Westlake SL, Colebatch AN, Baird J, et al. Tumour necrosis factor antagonists and the risk of cardiovascular disease in patients with rheumatoid arthritis: A systematic literature review. Rheumatology 2011;50(3):518531. [http://dx.doi.org/10.1093/rheumatology/keq316]

78. Vis M, Havaardsholm EA, Haugeberg G, et al. Evaluation of bone mineral density, bone metabolism, osteoprotegerin and receptor activator of the NFkB ligand serum levels during treatment with osteoprotegerin and receptor activator of the NFKB ligand serum levels during treatment with
infliximab in patients with rheumatoid arthritis. Ann Rheum Dis 2006;65(11):1495-1499. [http:// dx.doi.org/10.1136/ard.2005.044198]

79. van Staa TP, Leufkens HG, Cooper C. The epidemiology of corticosteroid-induced osteoporosis: A metaanalysis. Osteoporos Int 2002;13(10):777-787. [http://dx.doi.org/10.1007/s001980200108]

80. Grossman JM, Gordon R, Ranganath VK, et al. American College of Rheumatology 2010 recommendation for the prevention and treatment of glucocorticoid-induced osteoporosis. Arthritis Care Res 2010;62(11):1515-1526. [http://dx.doi.org/10.1002/acr.20295]

81. Baecklund E, Iliadou A, Askling J, et al. Association of chronic inflammation, not its treatment, with increased lymphoma risk in rheumatoid arthritis. Arthritis Rheum 2006;54(3):692-701. [http://dx.do org/10.1002/art.21675]

82. Askling J, van Vollenhoven RF, Granath F, et al. Cancer risk in patients with rheumatoid arthritis treated with anti-tumor necrosis factor a therapies: Does the risk change with the time since start of treatment? Arthritis Rheum 2009;60(11):3180-3819. [http://dx.doi.org/10.1002/art.24941]

83. Buch MH, Smolen JS, Betteridge N, et al. Updated consensus statement on the use of rituximab in patients with rheumatoid arthritis. Ann Rheum Dis 2012;70(6):909-920. [http://dx.doi.org/10.1136/ard.2010.144998]

84. Raaschou P, Simard JF, Neovius M, et al. Does cancer that occurs during or after anti-tumor necrosis factor therapy have a worse prognosis? A national assessment of overall and site-specific cancer survival in rheumatoid arthritis patients treated with biologic agents. Arthritis Rheum 2011;63(7):1812-1822. in rheumatoid arthritis patients treated
[http://dx.doi.org/10.1002/art.30247]

85. Boulman N, Rimar D, Rozenbaum M, et al. Anti-tumor necrosis factor treatment and pregnancy: The Boulman N, Rimar D, Rozenbaum M, et al. Anti-
way is open. Clin Exp Rheumatol 2012;30(3):453.

86. Visser K, Katchamart W, Loza E, et al. Multinational evidence-based recommendations for the use of methotrexate in rheumatic disorders with a focus on rheumatoid arthritis: Integrating systematic literature research and expert opinion of a broad international panel of rheumatologists in the $3 \mathrm{E}$ Initiative. Ann Rheum Dis 2009;68(7):1086-1093. [http://dx.doi.org/10.1136/ard.2008.094474]

87. Kavanaugh A. Economic consequences of established rheumatoid arthritis and its treatment. Best Pract Res Clin Rheumatol 2007;21(5):929-942. [http://dx.doi.org/10.1016/j.berh.2007.05.005]

88. Roy $S$. Number needed to treat for biologic therapies in patients with active rheumatoid arthritis despite methotrexate: A mixed treatment comparison meta-analysis. Abstract, EULAR Congress 2011. Ann Rheum Dis 2011;70(Supp13):432. http://www.abstracts2view.com/eular/view.php?nu=EULAR11L FRI0265\&terms $=$ (accessed 13 May 2013)

89. Schoels M, Wong J, Scott DL, et al. Economic aspects of treatment options in rheumatoid arthritis: A systematic literature review informing the EULAR recommendations for the management of rheumatoid arthritis. Ann Rheum Dis 2012;69(6):995-1003. [http://dx.doi.org/10.1136/ard.2009.126714] 